\title{
SYNERGISTIC INHIBITION OF SARS-CORONAVIRUS REPLICATION BY TYPE I AND TYPE II IFN
}

\author{
Eric C. Mossel, Bruno Sainz, Jr., Robert F. Garry, and C. J. Peters *
}

\section{INTRODUCTION}

The susceptibility of SARS-coronavirus (SARS-CoV) to interferon (IFN) treatment has been extensively examined in culture, animals, and the clinic. IFN- $\alpha$, relatively ineffective in cell culture, showed suggestive but inconclusive efficacy in monkeys and SARS patients. ${ }^{1,2}$ IFN- $\beta$ has most potent antiviral activity, though concentrations of greater than $1000 \mathrm{U} / \mathrm{ml}$ result in only marginal reduction of virus titer. ${ }^{3-7}$ IFN- $\gamma$ is ineffective against SARS-CoV in cell culture., ${ }^{3,5,6}$

It has been previously shown that treatment of cells with both type I and type II IFN produces an antiviral state greater in magnitude than can be explained by additive effects alone. $^{8-12}$ We sought to determine the effect of such an enhanced antiviral state on the replication of SARS-CoV.

\section{IFN- $\beta$ AND IFN- $\gamma$ SYNERGISTICALLY INHIBIT SARS-CoV REPLICATION}

To characterize the inhibitory effect of IFN- $\beta$ and IFN- $\gamma$ treatment on SARS-CoV replication, three-day viral growth assays were performed. IFN pretreated Vero E6 cells were infected with SARS-CoV at a MOI of 0.01 . Cultures treated with $100 \mathrm{U} / \mathrm{ml}$ of IFN$\beta$ or IFN- $\gamma$ were significantly refractory for SARS-CoV Urbani and HK replication ( $\mathrm{P}<$ 0.001 ) at 24 and 48 hpi (Figures 1a and 1b). By 72 hpi, however, viral titers in IFN- $\beta$ - or IFN- $\gamma$-treated cultures approached levels detected in vehicle-treated groups. A potent inhibitory effect was observed when Vero E6 cultures were treated with both IFN- $\beta$ and IFN- $\gamma$. The inhibitory effect achieved with combination IFN- $\beta$ and IFN- $\gamma$ treatment was

\footnotetext{
* Eric C. Mossel, Colorado State University, Fort Collins, Colorado 80523. Bruno Sainz, Jr., Scripps Research Institute, La Jolla, California 92307. Robert F. Garry, Tulane University Health Sciences Center, New Orleans, Louisiana 70112. C. J. Peters, University of Texas Medical Branch, Galveston, Texas 77555.
} 




B



Figure 1. IFN- $\beta$ and/or IFN- $\gamma$ inhibit SARS-CoV replication in Vero E6 Cells. Vero E6 cells were treated with $(\square)$ vehicle or $100 \mathrm{U} / \mathrm{ml}$ each of $(\bullet)$ IFN- $\beta,(\boldsymbol{\Lambda})$ IFN- $\gamma$ or $(\diamond)$ IFN- $\beta$ and IFN- $\gamma 12 \mathrm{~h}$ prior to infection with SARS-CoV strain (A) Urbani or SARS-CoV strain (B) HK at a MOI of 0.01 pfu per cell. Supernatants were harvested on the indicated days p.i., and viral titers were determined by plaque assay. Significant differences in viral titers in Vero E6 cells treated with IFNs relative to cells treated with vehicle are denoted by a single asterisk ( $\mathrm{P}<0.001$, one-way ANOVA and Tukey's post hoc $t$ test).

consistently greater than 3000 -fold at all time points tested and reached levels of greater than $1 \times 10^{5}$-fold at 72 hpi relative to vehicle treated Vero E6 cells.

\section{IFN- $\beta$ AND IFN- $\gamma$ SYNERGISTICALLY INHIBIT SARS-CoV-MEDIATED CPE}

Cytopathic effect (CPE) was extensive in vehicle-treated groups infected with either SARS-CoV strain at 120 hpi (Fig. 2A and 2E), as evident by the reduced monolayer staining with crystal violet. Relative to vehicle-treated and individual IFN-treated cultures, CPE is less evident in cells treated with both IFN- $\beta$ and IFN- $\gamma$ at $120 \mathrm{hpi}$; monolayers appeared evenly stained with little to no visible CPE (Fig. 2D and 2H).

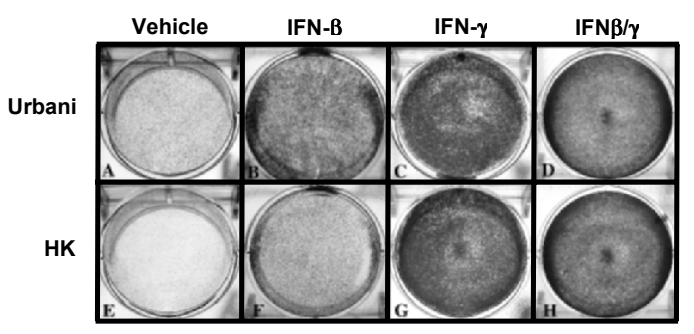

Figure 2. IFN- $\gamma$ alone and IFN- $\beta$ and IFN- $\gamma$ inhibit SARS-CoV CPE in Vero E6 cells. Cultures were pretreated for $12 \mathrm{~h}$ with (A, E) vehicle or $100 \mathrm{U} / \mathrm{ml}$ each of (B, F) IFN- $\beta$, (C, G) IFN- $\gamma$, or (D, H) IFN- $\beta$ and IFN- $\gamma$ prior to infection with SARS-CoV strains Urbani (A-D) or HK $(\mathrm{E}-\mathrm{H})$ at a MOI of $0.01 \mathrm{pfu} / \mathrm{cell}$. Monolayers were fixed, stained with crystal violet, and photographed $120 \mathrm{~h}$ p.i. 




Figure 3. IFN- $\beta$ and IFN- $\gamma$ inhibits SARS-CoV CPE in Calu-3 cells. Cultures were pretreated for $12 \mathrm{~h}$ with (A, E) vehicle or $100 \mathrm{U} / \mathrm{ml}$ each of $(B, F)$ IFN- $\beta,(C, G)$ IFN- $\gamma$, or $(D, H)$ IFN- $\beta$ and IFN- $\gamma$ prior to infection with SARS-CoV strain Urbani at a MOI of $0.01 \mathrm{pfu} / \mathrm{cell}$. Monolayers were fixed, stained with crystal violet, and photographed $72 \mathrm{~h}$ p.i.

To determine whether this phenomenon is limited to Vero E6 cells, additional cell lines were examined. Calu-3 cells showed the same gradated CPE as Vero E6 cells with little or no CPE present in cells treated with both IFN- $\beta$ and IFN- $\gamma$ (Fig. 3). Contrary to the observations of others, gross CPE does not occur in SARS-CoV-infected Caco-2 cells in our hands. ${ }^{3,13}$ As such, SARS-CoV-infected Caco-2 cell monolayers remained confluent regardless of treatment. However, the CPE profile observed in Calu-3 cells suggests that the synergistic inhibitory effect on SARS-CoV replication by IFN- $\beta$ and IFN- $\gamma$ is not Vero E6 cell specific.

\section{DISCUSSION}

It has been known for more than 25 years that treatment of cells with type I and type II IFN potentiates the antiviral response to levels greater than can be explained by simple additive effects. ${ }^{10}$ Since then, the effect has been shown for a wide variety of viruses, including human cytomegalovirus, HSV-1, vesicular stomatitis virus (VSV), Lassa virus, and others. ${ }^{8,9,11,12,14}$

The mechanism of synergistic inhibition of virus replication by type I and type II IFN has not been determined for any virus. However, it was recently shown that NO, induced by a combination of IFN- $\gamma$ and IL- $1 \beta$, inhibits SARS-CoV replication. ${ }^{15}$ Further, it was shown in an avian system that type I and type II IFN potentiate the antiviral response as well as the secretion of $\mathrm{NO}^{16}$ Based on this evidence, a role for NO and iNOS in the potentiated anti-SARS-CoV response induced by type I and type II IFN cotreatment deserves consideration.

\section{ACKNOWLEDGMENTS}

The authors wish to thank Dr. Dr. Li-Kuang Chen from Tzu-Chi University at Hualien, Taiwan for kindly supplying the SARS-CoV strain HK. This work is supported by National Institutes of Health grants AI007536 (E.C.M.), AI0543818 (B.S.), and AI054626, AI054238, RR018229, and CA08921 (R.F.G.) and contract NO1 AI 25489 (C.J.P.). 


\section{REFERENCES}

1. Haagmans, B. L., Kuiken, T., Martina, B. E., Fouchier, R. A., Rimmelzwaan, G. F., van Amerongen, G., van Riel, D., de Jong, T., Itamura, S., Chan, K. H., Tashiro, M., and Osterhaus, A. D., 2004, Pegylated interferon-alpha protects type 1 pneumocytes against SARS coronavirus infection in macaques, Nat. Med. 10:290-293.

2. Loutfy, M. R., Blatt, L. M., Siminovitch, K. A., Ward, S., Wolff, B., Lho, H., Pham, D. H., Deif, H., LaMere, E. A., Chang, M., Kain, K. C., Farcas, G. A., Ferguson, P., Latchford, M., Levy, G., Dennis, J. W., Lai, E. K., and Fish, E. N., 2003, Interferon alfacon-1 plus corticosteroids in severe acute respiratory syndrome: a preliminary study, JAMA 290:3222-3228.

3. Cinatl, J., Morgenstern, B., Bauer, G., Chandra, P., Rabenau, H., and Doerr, H. W., 2003, Treatment of SARS with human interferons, Lancet 362:293-294.

4. Hensley, L. E., Fritz, L. E., Jahrling, P. B., Karp, C. L., Huggins, J. W., and Geisbert, T. W., 2004, Interferon-beta 1a and SARS coronavirus replication, Emerg. Infect. Dis. 10:317-319.

5. Scagnolari, C., Vicenzi, E., Bellomi, F., Stillitano, M. G., Pinna, D., Poli, G., Clementi, M., Dianzani, F., and Antonelli, G., 2004, Increased sensitivity of SARS-coronavirus to a combination of human type I and type II interferons, Antivir. Ther. 9:1003-1011.

6. Spiegel, M., Pichlmair, A., Muhlberger, E., Haller, O., and Weber, F., 2004, The antiviral effect of interferon-beta against SARS-coronavirus is not mediated by MxA protein, J. Clin. Virol. 30:211-213.

7. Stroher, U., DiCaro, A., Li, Y., Strong, J. E., Aoki, F., Plummer, F., Jones, S. M., and Feldmann, H., 2004, Severe acute respiratory syndrome-related coronavirus is inhibited by interferon- alpha, J. Infect. Dis. 189:1164-1167.

8. Asper, M., Sternsdorf, T., Hass, M., Drosten, C., Rhode, A., Schmitz, H., and Gunther, S., 2004, Inhibition of different Lassa virus strains by alpha and gamma interferons and comparison with a less pathogenic arenavirus, J. Virol. 78:3162-3169.

9. Czarniecki, C. W., Fennie, C. W., Powers, D. B., and Estell, D. A., 1984, Synergistic antiviral and antiproliferative activities of Escherichia coli-derived human alpha, beta, and gamma interferons, J. Virol. 49:490-496.

10. Fleischmann, W. R., Jr., Georgiades, J. A., Osborne, L. C., and Johnson, H. M., 1979, Potentiation of interferon activity by mixed preparations of fibroblast and immune interferon, Infect. Immun. 26:248-253

11. Sainz, Jr., B., and Halford, W. P., 2002, Alpha/Beta interferon and gamma interferon synergize to inhibit the replication of herpes simplex virus type 1, J. Virol. 76:11541-11550.

12. Schwarz, L. A., Fleischmann, C. M., and Fleischmann, Jr., W. R., 1984, Potentiation of interferon's antiviral activity by the mutually synergistic interaction of MuIFN-alpha/beta and MuIFN-gamma, J. Biol. Response Mod. 3:608-612.

13. Sainz, Jr., B., Mossel, E. C., Peters, C. J., and Garry, R. F., 2004, Interferon-beta and interferon-gamma synergistically inhibit the replication of severe acute respiratory syndrome-associated coronavirus (SARSCoV), Virology 329:11-17.

14. Sainz, Jr., B., Lamarca, H. L., Garry, R. F., and Morris, C. A., 2005, Synergistic inhibition of human cytomegalovirus replication by interferon-alpha/beta and interferon-gamma, Virol. J. 2:14.

15. Akerstrom, S., Mousavi-Jazi, M., Klingstrom, J., Leijon, M., Lundkvist, A., and Mirazimi, A., 2005, Nitric oxide inhibits the replication cycle of severe acute respiratory syndrome coronavirus, J. Virol. 79:19661969.

16. Sekellick, M. J., Lowenthal, J. W., O’Neil, T. E., and Marcus, P. I., 1998, Chicken interferon types I and II enhance synergistically the antiviral state and nitric oxide secretion, J. Interferon Cytokine Res. 18:407-414. 